Agro-Science Journal of Tropical Agriculture, Food, Environment and Extension Volume 19 Number 2 (Apr. 2020) pp. 48 - 52

ISSN 1119-7455

\title{
ADAPTIVE STRATEGIES TO DEFORESTATION AMONG NON-TIMBER FOREST PRODUCTS (NTFPS) COLLECTORS ACROSS GENDER LINE IN OLUWA FOREST RESERVE AREA OF ONDO STATE, NIGERIA
}

\author{
${ }^{* 1}$ Aluko O.J., ${ }^{2}$ Adejumo A.A. and ${ }^{3}$ Bobadoye A.O. \\ ${ }^{1}$ Department of Agricultural Extension \& Management, \\ Federal College of Forestry, Jericho-Ibadan, Nigeria \\ ${ }^{2}$ Department of Agricultural Extension \& Rural Development, University of Ibadan, Nigeria \\ ${ }^{3}$ Research Coordinating Unit, Forestry Research Institute of Nigeria (FRIN), Ibadan, Nigeria \\ *Corresponding author's email: juliwal2002@yahoo.com
}

\begin{abstract}
Forest and the goods and services they provide are essential for human livelihood and wellbeing. An assessment on the likely impact of deforestation on NTFPs along gender line is therefore imperative for effective adaptations for NTFPs collectors. The study examined the adaptive strategies to deforestation stress employed among NTFPs collectors across gender line in Oluwa Forest Reserve area of Ondo State, Nigeria. Multistage sampling technique was used to select respondents for the study. Data were collected with the aid of well-structured interview schedule on 181 NTFPs collectors (94 males and 87 females) and analysed using descriptive statistics and inferential statistics. The data targeted socio-economic characteristics, level of availability of (NTFPS) in the mist of deforestation currently and 30 years ago as well as adaptive strategies employed by the respondents in the study area. Findings revealed that average age of male and female respondents were 48 and 43 years, respectively. Bitter Kola, Kola Nut, Mango and Walnut were NTFPs available in abundant 30 years ago. In recent years, the study discovered that only Mango and Walnut were available in excess despite persistent deforestation in the study area. Deforestation impacted more on female collectors compared to their men counterpart. The finding also shows that female collectors employed more of domesticated NTFPs and indigenous protection methods as adaptive strategies against deforestation. The study recommended training on scientific domesticated system of planting (NTFPs) for both male and female NTFPs collectors as well as community policing to cope against deforestation in the study area.
\end{abstract}

Key words: adaptive strategies, deforestation, non-timber forest products (NTFPs), gender

\section{INTRODUCTION}

Forest resources provide ample goods and services ranging from timber and non-timber products. These products serve as the sources of livelihood and food security for the dwellers living within and around forest reserves area of developing countries of subSahara Africa. The importance of Non-Timber Forest Products (NTFPs) cannot be overemphasised. The NTFPs have been found to play an important role in the livelihood of rural communities (Odebiyi and Ogunjobi, 2003; Jimoh and Adebisi, 2005; Balogun et al., 2014). Similarly, Ikoji et al. (2003) noted that most rural households meet their immediate needs through the collection of NTFPs. Nigeria is one of the most forested countries in West Africa, with 445 gazetted reserves and the forest canopy occupy about 10 million ha representing almost $10 \%$ of the total land area of 92,376,700 hectares (FAO, 2015). The gazetted reserves are categorized into forest reserves, free area, game reserves and national parks, all spread across six geopolitical zones of the country.
Among the geopolitical zones, South West in the southwestern part of country has the highest number of natural forest reserves. Faleyimu et al. (2013) reported 78 forest reserves in their study on state of forest regeneration in South West Nigeria. The states in this geopolitical zone depend on the resources from the forests to generate revenue and to support in the area of employment opportunities for the people residing in the state. Ondo State is one of such states in South West Nigeria that depend wholly on her forestry resources. The state has 17 forest reserves, with about $16.4 \%$ of the total land area demarcated as forest reserves (Agbelusi, 1994; Azeez and Aluko, 2019). The state forestry is contributing larger percentage to the state revenue yearly and the main sources of the revenue are from both timber products and nontimber products. Akindele (2003) reported that Ondo State generated over $\$ 600$ million Naira (equivalent to $\$ 28,571,428$ ) mainly from wood and tariff on forest products from the reserves for the period between 1996 and 2000. 
Oluwa forest reserve in among the 17 forest reserves in Ondo state and the largest forest reserves in the state and covers over $829 \mathrm{~km}^{2}$ of land .It is noteworthy that people dwelling around Oluwa forest reserves in the state constitute an integral part of the forest ecosystem as they depend on the forest for income, housing materials, clothing and the likes. However a major problem affecting the forest reserve is that of deforestation which has been attributed to massive illegal timber harvesting, logging, and clearing of forest for agricultural purposes as well as expansion of rural areas and villages into forest regions as a result of population growth and development. Deforestation often comes with much stress ranging from reduction in soil fertility, environmental pollution, health and disease outbreak as well as loss of forest resources. The effect of deforestation can also pose a negative impact on gatherers of NTFPs thus affecting their livelihood and standard of living.

In a bid to reducing the resultant effects of deforestation stress, rural households are compelled to develop some adaptation strategies. Adaptation strategy is defined as an adjustment in response to actual or expected climatic stimuli which moderates harm or exploits beneficial opportunities (Ravindranath, 2007). With respect to deforestation, adaptations would require ability to reduce vulnerability to current and future risk while vulnerability will largely lie on individuals or people's adaptive capacity. It is noteworthy that deforestation stress may likely affects gender differently since men and women have varied needs, concerns, inequitable distribution of resources, rights and ability to take actions. Hence understanding the situation of different gender group relative to each other becomes imperative so as to understand the difference in vulnerability and adaptive capacity between women and men. Attempts have been made by previous scholars to study the effect of deforestation (Oladosu et al., 2002). However, there has been a dearth of information on the adaptation of deforestation along gender line. It is against this backdrop that this study examined the adaptive strategies of deforestation among NTFPs collectors across gender line in Oluwa Forest Reserve Area of Ondo State, Nigeria. The specific objectives of the study are to (i) describe the socioeconomic characteristics of respondents, (ii) ascertain the level of availability of NTFPs in the mist of deforestation currently and 30 years ago, (iii) determine the extent in which deforestation impacted on collectors of NTFPs along gender line, and (iv) determine the difference in adaptive capacity between women and men NTFPs collectors in relation to the effects of deforestation.

\section{MATERIALS AND METHODS}

The study was carried out in Oluwa Forest Reserve area located at Ondo State, Nigeria. $\left(6^{\circ} 55^{\prime}-7^{\circ} 20^{\prime} \mathrm{N}\right.$ and $3^{\circ} 45^{\prime}-4^{\circ} 32^{\prime}$ E). Oluwa Forest Reserve is a gazetted reserve located in Odigbo Local Government Area of Ondo State and covers over 82900 ha of land. The vegetation of the reserve is characterized by rainy season which occurs from March till November while the dry season, is from December till February. Annual rainfall ranges from 1700 to $2200 \mathrm{~mm}$. Mean annual mean temperature in Oluwa is $26{ }^{\circ} \mathrm{C}$. (Ogunjemite and Olaniyi, 2012). Agriculture and gathering of NTFPs are the major economic activity among rural dwellers within and around the forest reserve.

The population of the study was registered NTFPs collectors within and around the forest reserve. Data were generated from NTFPs collectors through the use of interview schedule, focus group discussions (FGD). Multistage sampling technique was used to select respondents for the study. Three settlements were purposively selected due to predominance of NTFPs gathering. The selected villages are Makinde, Ogunlepa and Onipetesi. From a list of registered NTFPs collectors in the settlements, the population was stratified into male and female NTFPs collectors. Sixty percent of the NTFPs collectors were randomly selected across the villages to give a sample size of 181 NTFPs collectors (94 males and 87 females).

Data were analysed using descriptive (frequency distribution, mean and percentages) and inferential (t-test) statistics. The level of availability of NTFPs in the mist of deforestation was measured through memory recall. Respondents were asked to indicate the extent to which NTFPs were available 30 years ago and currently. This was measured on a three point scale of increase, no change and decline. Scores of 2, 1 and 0 were assigned, respectively. The mean distribution was used to rank the availability of NTFPs for 30 years ago and currently. Extent to which deforestation impacted on collectors of NTFPs was measured on a three point scale of more, less and no effects. Scores of 2, 1 and 0 were assigned, respectively.

The mean scores were generated and used to rank each of the effects as perceived by the respondents. The adaptive strategies used by respondents were measured on a three point scale of always, sometimes and never, scores of 2, 1 and 0 were assigned respectively. The mean score was used to rank each of the adaptation strategies in order of utilization. T-test analysis was used to test the difference in adaptation strategies between women and men NTFPs collectors in relation to the effects of deforestation 


\section{RESULTS AND DISCUSSION Socio Economic Characteristics}

The socio-economic characteristics of the respondents are presented in Table 1 . The mean age of male and female respondents was 48 and 43 years, respectively. This suggests that that the age distribution is not different across gender as they both fall within the middle age category. This finding is in congruence with Dau and Elisha (2014) that NTFPs gatherers falls within the middle age bracket. Furthermore, $55.2 \%$ of the female respondents had primary education while $40.4 \%$ and $2.1 \%$ of the males had secondary and tertiary education, respectively. This implies that male respondents were more educated than female. This finding is in consonance with Akinbi and Akinbi (2015) who reported similar result that in most rural communities in Nigeria, preference is given to male education. Furthermore, the average monthly income of male and female respondents was $\$ 19,448.33$ (\$53.23) and $\$ 13,663.50$ (\$37.43), respectively. This suggests that male respondents earned more income than their female counterpart. This could be as a result of men having more access to natural resources. This finding is in line with Rauch et al. (2016) who reported low income earnings among rural women than men as a result of limited control over resources.

\section{Mean Distribution on the Availability of NTPFs} Data obtained in Table 2 revealed that Bitter Kola $($ mean $=2.79)$, Kola Nut, $($ mean $=2.79)$ Mango (mean $=2.74$ ) and Walnut (mean $=2.68$ ) were available in abundance 30 years ago, while in recent years, the study discovered that only Mango $($ mean $=2.17)$ and Walnut $($ mean $=2.14)$ were available in excess despite persistent deforestation in the study area. The decline in the availability of NTPFs could pose negative effect on the livelihood of NTFPs gatherers in the study area. This finding is line with Adejumo et al. (2016) who reported that increased deforestation accounted for livelihood loss among NTPFs collectors. This is corroborated by discussants during the focus group discussion in Oluwa Forest Reserve with submission that:
"Bitter Kola is an ancient non-timber forest product in the reserves and dwellers threshed the trees in the years back due to the fact that most of the dwellers inherited the tree from their families and the bitter Kola stands are passed from one generation to the other but deforestation is regularly reducing the availabilities of the tree in the reserve.

In the related development, participants also reported thus:

"Only few Bitter Kola trees are available in the reserves in recent time because they are basically use for traditional rites as the seed is perceived as a means of consulting oracles or gods of the land".

\section{Difference in Perceived Effect of Deforestation on NTFPs Activities across Gender}

Table 3 shows that reduction in income ranked highest among male (mean $=2.57$ ) and female (2.63) as a major effect to deforestation. Other effect of deforestation on NTFPs as perceived by the males include: land use conflict $($ mean $=2.42)$ and Reduction in NTFPs (mean $=2.24)$, while extinction in medicinal herbs $($ mean $=2.56)$ and reduction in NTFPs (mean $=2.54$ ) were noticeable among the female respondents. This further revealed a decline in forest resources owing to deforestation. This is in line with Aluko et al. (2015) who reported that resources are reduced across gender line whenever disaster befalls any rural communities .This implies that the effect of deforestation has impacted negatively on the activities of NTFPs. In one of the focus group discussion, one of the participants reported thus:

"Income generated from Non-timber forest products reduces every year, as a result of massive occurrence of deforestation which has led to decrease in the standard of living of the collectors of nontimber forest product in the area."

Furthermore, One of the stakeholders during indepth interviewed reported thus:

"Deforestation of timber products in the forest reserve translated to destruction of non-timber forest products due to the fact that many of the NTFPs are located or positioned among the timber products in the area. An attempt to cut down the timber trees resulting into felling of non-timber forest products closer to the timbers."

Table 1: Distribution by socio economic characteristics of respondents

\begin{tabular}{|c|c|c|c|c|c|c|}
\hline \multirow[t]{2}{*}{ Variable } & \multicolumn{3}{|c|}{ Male $(\mathrm{N}=94)$} & \multicolumn{3}{|c|}{ Female $(\mathrm{N}=87)$} \\
\hline & Freq. & $\%$ & Mean & Freq. & $\%$ & Mean \\
\hline \multicolumn{7}{|l|}{ Age } \\
\hline 41-50 year & 50 & 53.1 & 48 years & 59 & 67.8 & 43 years \\
\hline Above 60 years & 9 & 9.7 & & 0 & 0 & \\
\hline \multicolumn{7}{|l|}{ Education } \\
\hline Non formal & 22 & 23.4 & & 48 & 55.2 & \\
\hline Tertiary & 2 & 2.1 & & 1 & & \\
\hline \multicolumn{7}{|l|}{ Income(monthly) } \\
\hline$<® 10,000$ & 7 & 7.5 & & 10 & 11.5 & \\
\hline $10,000-19,999$ & 32 & 34.0 & $\mathrm{~N} 19,448.33$ & 55 & 63.2 & $\approx 13,663.50$ \\
\hline N20,000- 29,999 & 44 & 46.8 & & 18 & 20.7 & \\
\hline
\end{tabular}


Table 2: Mean distribution on the availability of NTPFs

\begin{tabular}{lcc}
\hline NTFPs & 30 years ago & Recently \\
\hline Fuel wood & 2.58 & 1.86 \\
Kolanut & 2.79 & 1.77 \\
Walnut & 2.68 & 2.14 \\
Herbs & 2.66 & 1.92 \\
Mango & 2.74 & 2.17 \\
Bitter kola & 2.79 & 1.72 \\
Chewing stick & 2.48 & 1.85 \\
Mushroom & 2.16 & 1.81 \\
\hline
\end{tabular}

Source: Field survey, 2019

Table 3: Distribution by perceived effect of deforestation on NTFPs activities

\begin{tabular}{lcccc}
\hline Perceived effect & $\begin{array}{c}\text { Male } \\
\text { Mean }\end{array}$ & Rank & $\begin{array}{c}\text { Female } \\
\text { Mean }\end{array}$ & Rank \\
\hline $\begin{array}{l}\text { Extinction of } \\
\text { medicinal herbs }\end{array}$ & 2.20 & $4^{\text {th }}$ & 2.56 & $2^{\text {nd }}$ \\
$\begin{array}{l}\text { Low income } \\
\text { Reduction in }\end{array}$ & 2.57 & $1^{\text {st }}$ & 2.63 & $1^{\text {st }}$ \\
$\begin{array}{l}\text { NTFPs } \\
\begin{array}{l}\text { Land use } \\
\text { conflict }\end{array}\end{array}$ & 2.24 & $3^{\text {rd }}$ & 2.54 & $3^{\text {rd }}$ \\
$\begin{array}{l}\text { Extinction } \\
\text { of fauna }\end{array}$ & 1.72 & $2^{\text {nd }}$ & 2.30 & $5^{\text {th }}$ \\
\hline
\end{tabular}

Source: Field Survey, 2019

The t-test on Table 4 further reveals a significant difference in the effect of deforestation across gender $(t=2.38, p=0.019)$. The mean difference suggests that the effect of deforestation impacted more on women than men in the study area. The plausible reason for this could be attributed to their low level of education as well as access to resources. In addition, cultural norms may hinder the ability of women to take decisions on whether to move to safer grounds in the mist of deforestation. This finding agrees with Alston (2013) and Nursey-Bray (2015) that shocks emanating from environmental effects often pose much effect on women due to inequitable distribution of rights, assets, resources and power as well as repressive cultural rules and norms, and greater responsibilities.

Respondents' Adaptive Strategies to Deforestation The mean distribution of the adaptation strategies employed by respondents in Table 5 reveals that both male $($ mean $=2.41)$ and female $($ mean $=2.49)$ respondents ascribe names of deity in forest location to scare individuals from encroaching into the areas. Other adaptation strategies utilised by male respondents include use of charms to protect trees $($ mean $=2.46)$, community policing $($ mean $=2.17)$ and domestication of NTFPs (mean $=2.11)$. Similar result was found among the female respondents as the use of charms to protect the forest trees (mean = $2.46)$, domestication of NTFPs (mean $=2.36$ ) and use of agroforestry practices (mean $=2.32$ ) were also utilised. This implies that both male and female respondents in the study area employed more of domestication and indigenous protection methods as adaptive strategies.
Table 4: Difference in extent in which deforestation impacted on collectors of NTFPs along gender line

\begin{tabular}{llllll}
\hline & Mean & SD & T & Df & p \\
\hline Male & 9.6 & 2.43 & 2.38 & 179 & 0.019 \\
Female & 12.7 & 1.83 & & & \\
\hline Source: Field Survey, 2019 & & &
\end{tabular}

Table 5: Distribution by adaptation strategies to deforestation employed by respondents

\begin{tabular}{lcc}
\hline Adaptation strategies & Male & Female \\
\hline Use of efficient fuel stove & 1.87 & 0.96 \\
Tree planting & 1.44 & 1.73 \\
Domestication of some NTFPs & 2.11 & 2.36 \\
Blockage of access road & 2.03 & 1.26 \\
$\begin{array}{l}\text { Protecting economic tree through } \\
\text { the use of charms }\end{array}$ & 2.17 & 2.46 \\
Community policing & 2.40 & 2.27 \\
Engage in agroforestry & 1.56 & 2.32 \\
Ascribing names of deity to forest area & 2.41 & 2.49 \\
\hline
\end{tabular}

Source: Field survey, 2019

In the in-depth interview conducted in the course of the study, one of the leaders reported thus:

"The best strategy to prevent cutting down of non-timber forest products is through the use of African magic, voodoo and charms. This as reported by the leader will avert encroachers from touching any of the trees in the area".

This observation buttresses the findings by Nyabwari and Kagema (2014) that traditional beliefs are held in esteem in African society.

The t-test analysis (Table 6) shows a significant difference in the adaptive strategies employed across gender. This suggests that adaptive strategies employed by men and women are not the same in the study area. The mean distribution further suggests that women NTFPs collectors employed more of the adaptive strategies compared to their male counterpart. It is also an indication that women NTFPs gatherers have a clear idea about what they need and what may likely threaten their source of livelihood despite their constraints. This finding is in line with Chanda et al. (2017) that women are often innovative and willing to change practices which may likely increase the risk for being hit by shocks or environmental stress.

Table 6: Difference in adaptation strategies to deforestation along gender line

\begin{tabular}{llllll}
\hline & Mean & SD & T & Df & p \\
\hline Male & 10.8 & 2.97 & 21.7 & 179 & 0.000 \\
Female & 13.4 & 4.12 & & &
\end{tabular}

Source: Field Survey, 2019 


\section{CONCLUSION AND RECOMMENDATION}

The study concludes that deforestation impacted on both male and female NTFPs gatherers. However, female NTFPs gatherers were more affected. The study also revealed that female NTFPs gatherers employed more of adaptive strategies to deforestation. Hence, women can be said to be repositories of knowledge in managing natural resources, helping their families survive during shocks, and hold an array of experiences which can be useful for developing gender sensitive adaptation strategies for addressing deforestation. The study therefore recommended the need for training on scientific domesticated system of planting (NTFPs) for both male and female NTFPs collectors as well as community policing to militate against deforestation in the study area.

\section{REFERENCES}

Adejumo A.A., Aluko O.J., Marizu J.T. and Ajanaku A.O. (2016). Adaptive strategies of deforestation employed by non timber forest products collectors in Okomu Forest Reserve, Edo State, Nigeria. Commonwealth Forestry Association (CFA) Conference Proc., 1, 37-41

Agbelusi E.A. (1994). Wildlife conservation in Ondo State. Nigerian Field, 59, 73-83

Akindele S.O. (2003). Protection of our forest: the challenges. Invited Paper Presented at the workshop Organized by Ondo State Ministry Agriculture, Fisheries and Forest Resources, 4 Nov. 2003, Akure

Akinbi J.O. and Akinbi Y.A. (2015). Gender disparity in enrolment into basic formal education in Nigeria: implications for national development. AFRREV, 9 (3), 11-23

Alston M. (2013). Gender mainstreaming and climate change. Women's Studies International Forum, 1-8

Aluko O.J., Adejumo A.A. and Samuel O.F. (2015). Gender analysis of adaptation strategies on water stress among arable crop farmers in Asa Local Government Area of Kwara State, Nigeria. Paper presented at CCDA-5, $5^{\text {th }}$ Climate Change and Development in Africa, 28-30 Oct., 2015 in Victoria Falls, Zimbabwe

Azeez I.O. and Aluko O.J. (2019). Analysis of factors instigating land use conflicts in selected forest reserves of Ondo State, Nigeria. J. Environ. Protection, 10, 614 624. https://doi.org/10.4236/jep.2019.105036

Balogun O.L., Yusuf S.A., Osalusi C.S., Olowe O.O. and Ayo Bello T.A. (2014). Determinants of market participation in non-timber forest products among households of rain forest in Ondo State, Nigeria. $J$. Forestry Social Sci., 12 (2), 18-33
Chanda G.C., Manjari M. and Suman B. (2017). Status of gender vulnerabilities and adaptations to climate change in Hindu Kush Himalaya: Impacts and implications for households and sustainable mountain development. Int. Centre for Integrated Mountain Development Working Paper, 3, 1-78

Dau J.H. and Elisha A. (2014). Survey on non-timber forest products in Bauchi South Senatorial Districts, Bauchi State, Nigeria. J. Res. Forestry, Wildlife Environ., 6 (1), 82-97

Faleyimu O.I., Agbeja B.O. and Akinyemi O. (2013). State of forest regeneration in Southwest Nigeria. Afr. J. Agric. Res., 8 (26), 3381-3

FAO (2015). Global Forest Resources Assessment, 2014 Country Report Nigeria. Food and Agricultural Organization (FAO), Rome, 1-82

Ikoji H.A., Udofia S.I. and Azeez I.O. (2003). Community forestry approach to poverty alleviation in rural areas. In: Akindele S.O. and Popoola L. (eds.), Proc. $29^{\text {th }}$ Annual Conference of the Forestry Association of Nigeria (FAN), 6-11 Oct., 2003, pp. 1-8

Jimoh S.O. and Adebisi S.R. (2005). Non-timber forest products and susutainable forest management in Nigeria. In: Popoola L., Mfom P. and Oni P.I. (eds.), Proc. $30^{\text {th }}$ Annual Conference of FAN held in Kaduna, Kaduna State, Nigeria, 7-11 Nov., 2005, pp. 266-271

Nursey-Bray M. (2015). Gender, Governance And Climate Change Adaptation. Handbook of Climate Change Adaptation, Vol 1. Dordrecht, The Netherlands: Springer, pp. 1077-1090

Nyabwari B.G. and Kagema G.N. (2014). The impact of magic and witchcraft in the social, economic, political and spiritual life of African communities. Int. J. Humanities Soc. Sci. Edu., 1 (5), 9-18

Odebiyi J.B. and Ogunjobi M. (2003). Role of non timber forest products in alleviating poverty in Odeda Local Government Area of Ogun State, Nigeria. In: Akindele S.O. and Popoola L. (Eds.) Proceedings of the $29^{\text {th }}$ Annual Conference of the FAN held in Calabar between $6^{\text {th }}$ and $11^{\text {th }}$ October, 2003. pp. 59-71

Ogunjemite B.G. and Olaniyi O.E. (2012). The chimpanzees of Oluwa Forest Reserve, Southwest Nigeria. Int. J. of Dev. Sustainability, 1 (3), 823-833

Oladosu I.O., Ogunwale A.O. and Ayanwuyi E. (2002). Framers' perception of effects of deforestation on agricultural production and economics activities in selected rural communities in Orire Local Government Area of Oyo State, Nigeria. Int. J. Business Common Market Studies, 1 (1), 209-216

Rauch T., Beckmann G., Neubert S., Rettberg S. (2016). Rural transformation in Sub-Saharan Africa conceptual Study. SLE Discussion Paper. Centre for Rural Development (SLE) Berlin

Ravindranath N. (2007). Mitigation and adaptation synergy in forest sector. Mitigation and Adaptation Strategies for Global Change, 12 (5), 843-853 